\title{
Genetic Characteristics and Phylogenetic Analysis of Influenza Type B Viruses Isolated from Nasopharyngeal Suction Samples of Korean Patients
}

\author{
Yun Hee Baek, Young Jun Song, Min-Suk Song, Philippe Noriel Q. Pascua, Jun Han Lee, \\ Heon-Seok Han, Sung-Il Woo, Seok-Yong Kim and Young-Ki Choi* \\ College of Medicine and Medical Research Institute, Chungbuk National University, Cheongju, Korea
}

\begin{abstract}
To investigate the genetic characteristics of human influenza type B viruses circulating in Chungbuk province, Korea, we tested 510 clinical samples of nasopharyngeal suction from pediatric patients diagnosed with respiratory illness between June 2007 and June 2008. Twelve out of thirty-six isolates were identified as type B influenza virus by RT-PCR and sequencing analysis. Interestingly, genetic characterization of type B viruses isolated in this study revealed that all type B influenza viruses were the Yamagata lineages, a vaccine strains of southern hemisphere during 2007 2008, rather than the Victoria lineage of northern hemisphere during 2007 2008. Furthermore, there were a total of twelve unique mutations (HA: H40Y, D/G230S, V252M and K272R and NA: P3H, P/T/S42Q, N59S) occurred in our type B isolates. These results suggest that relative high prevalence of type B viruses in Korea during 2007 2008 season might be due to the wrong vaccine strains selection. Taken together, the results of this study demonstrate continuous evolutions of human type B viruses by antigenic drift and also highlight the need to closely monitoring of influenza viruses to aid the early detection of potentially pandemic strains as well as underscore the need for new therapeutics.
\end{abstract}

Key Words: Influenza B virus, Antigenic drift, Phylogenetic analysis, Vaccine strain

\section{서 론}

인플루엔자 바이러스는 중요한 호흡기 병원균으로서 매년 세계적으로 유행하며 인플루엔자와 관련된 사망자 는 매년 증가하여 250,000 500,000명에 이른다 (WHO, 2003). 북반구에서는 주로 겨울철에 유행을 일으키고 소 아나 고령층에서 높은 감염률을 보이며 때로는 심각한 호흡기 합병증으로 사망에 이르기까지 하는 중요한 급 성 전염성 호흡기 질환을 일으키는 바이러스이다 $(1,2)$.

Received: May 1, 2009/ Revised: June 3, 2009

Accepted: June 5, 2009

* Corresponding author: Young Ki Choi. College of Medicine and Medical Research Institute, Chungbuk National University, 12 Gaeshin-Dong, Heungduk-Ku, Cheongju 361-763, Korea.

Phone: +82-43-261-3384, Fax: +82-43-272-1603

e-mail: choiki55@chungbuk.ac.kr

** This work was supported by internal fund from Chungbuk National University in 2008.
Orthomyxoviridae에 속하는 인플루엔자 바이러스는 크게 $\mathrm{A}, \mathrm{B}$ 및 $\mathrm{C}$ 형으로 구분되며 게놈은 8 개의 negative strand RNA 분절로 구성되어 있다 (3). 이러한 분절 구조에 의 해 숙주간 전파를 통한 각 유전자 재조합에 의한 항원 의 변이를 가져와 새로운 바이러스가 출현할 수 있으며 세계적 대유행이 발생할 수 있는 기회를 제공하게 된다 (2 5). 인플루엔자 바이러스는 haemagglutinin (HA), neuraminidase (NA), nucleoprotein (NP), matrix protein (M1 그리 고 $\mathrm{M} 2$ ), nonstructural protein (NS1 그리고 NS2), polymerase protein $(\mathrm{PB} 2, \mathrm{~PB} 1, \mathrm{PA})$ 의 10 개의 유전자들이 8 개의 RNA 분절로 게놈을 형성하는데, $\mathrm{B}$ 형 바이러스는 $\mathrm{A}$ 형 바이러 스와는 달리 neuraminidase가 NA와 NB로 구분되는 특징 을 가지고 있다. 이 $\mathrm{NB}$ 단백은 인플루엔자 $\mathrm{A}$ 바이러스에 서의 M2 단백의 기능을 하고 있으며 $(6,7) \mathrm{B}$ 바이러스 의 matrix 단백인 $\mathrm{M} 2$ 단백의 기능은 $\mathrm{A}$ 바이러스와는 달 리 아직 구체적으로 알려진 바가 없다 $(8,9)$. 사람에 주로 감염되는 인플루엔자 바이러스는 $\mathrm{A}$ 형인 
$\mathrm{H} 1 \mathrm{~N} 1, \mathrm{H} 3 \mathrm{~N} 2$ 의 혈청형과 인플루엔자 B형이며, 전 세계적 으로 매년 유사한 형이 유행하고 있다 $(4,10)$. A형 인플 루엔자 바이러스는 1918년 전세계적으로 2천만명 이상 의 희생자를 내었던 스페인 인플루엔자 바이러스 (H1N1) 를 포함한 16 개의 $\mathrm{HA}$ 항원형과 9 개의 NA 항원형을 가 지고 있다. 반면 $\mathrm{B}$ 형 인플루엔자 바이러스는 항원형이 구분되어지지 않고 Victoria lineage와 Yamagata lineage의 두 계통만으로 구분되는데, 이는 1983년 이래로 HA 유 전자의 계통학적 관계로 정의되었으며 (1) 1987년부터 11 개의 모든 단백질을 이 두 개의 계통으로 구분하기 시 작했다 $(1,4,10,11)$.

인플루엔자 $\mathrm{B}$ 형 바이러스는 유전적 변이, 삽입, 결손 등을 포함한 $\mathrm{HA}$ 유전자의 항원소 변이율이 인플루엔자 A형 바이러스에 비해 적다 (12 15). 그러나 1990년대 초 반에 처음으로 Yamagata lineage의 HA와 Victoria lineage 의 NA 유전자가 재배열된 인플루엔자 B형 바이러스가 보고된 바 있다 (14). 2002년 타이완에서 Yamagata lineage 와 Victoria lineage에 모두 속하는 바이러스가 분리되었 고, 다음해의 2004 2005, 2006 2007에 유행한 바이러스 의 유전적 관계에 대한 연구에 의하면 전세계적으로 각 지역에 따라 혼합형 바이러스가 검색되고 있으며, 혼합 형 유전자형의 분리 빈도가 다양하게 변화되고 있어 역 학적으로 중요한 과제가 되고 있다 $(1,16,17)$.

국내에서의 A형 인플루엔자 바이러스에 대한 연구는 활발히 진행되고 있지만 인플루엔자 $\mathrm{B}$ 형에 대한 국내의 연구는 미흡한 실정이다 (18). 본 연구에서는 2007년 6월 부터 2008년 6월까지 청주지역에서 발생한 호흡기 환자 인두 분비물에서 reverse transcription polymerase chain reaction (RT-PCR) 방법을 이용한 인플루엔자 B형의 발병 율과 바이러스 분리 및 유전자 분석을 통하여 국내에서 유행하고 있는 인플루엔자 $\mathrm{B}$ 형 바이러스의 계통 및 유 전적 변이를 알아보았다.

\section{재료 및 방법}

\section{세포 배양}

MDCK (Madin-Darby canine kidney) 세포는 MEM (minimal essential medium) 배지에 5\% 우태아혈청 (fetal bovine serum)과 페니실린/스토렙토마이신을 첨가한 배양 액을 사용하였으며, 감염 후에는 우태아혈청이 없는 배지 에 $1 \mu \mathrm{g}$ 의 TPCK (tosyl phenylalanyl chloromethyl ketone)- trypsin을 첨가하여 사용하였다.

$\mathrm{MDCK}$ 세포는 $33^{\circ} \mathrm{C}$ 와 $37^{\circ} \mathrm{C}, 5 \% \mathrm{CO}_{2}$ incubator에서 2 3 일마다 계대 배양하였으며 세포는 ATCC (America Type Culture Collection, Manassa, VA, USA)로부터 구입하였다.

검체의 채취 및 처리

Mucus trap과 카테터를 이용하여 환아들의 인두에서 비흡인물 (nasal aspirate)을 채취하였다. 모든 검체는 채취 한 후 신속히 검사실로 운반하였고 운반이 지연되는 경 우에는 $4^{\circ} \mathrm{C}$ 에서 냉장 보관하였다. 검체를 적절히 나누어 일부는 단층 배양된 $\mathrm{MDCK}$ 세포에 접종하여 바이러스의 배양 분리에 이용하였다.

\section{MDCK 세포를 이용한 바이러스의 분리}

12 well plate에 단층 배양된 MDCK 세포를 PBS로 2번 세척한 후 TPCK-trypsin은 포함되고 우태아혈청은 포함 되지 않은 $\mathrm{MEM}$ 으로 교환한 후 각 세포의 시험관 2개씩 에 검체를 접종하고 1 2시간 동안 흡착시킨 후 TPCKtrypsin이 포함된 $\mathrm{MEM}$ 으로 배지를 교환하였다. 1 2일 간격으로 인플루엔자 바이러스의 세포병변효과가 관찰될 때 또는 관찰되지 않을 경우에는 검체접종 3 일, 5 일째 에 닭의 적혈구 $(0.5 \%)$ 로 혈구응집검사 (hemagglutination assay)를 하여 양성반응을 보이는 시험관의 세포에서 $\mathrm{RNA}$ 를 추출하여 RT-PCR을 통하여 바이러스 게놈 존재 유무를 확인 후 분리된 바이러스는 즉시냉동 (snap freeze) 하여 $-70^{\circ} \mathrm{C}$ 에 냉동 보관하였다.

\section{RNA 추출}

Viral RNA 추출은 RNeasy Mini Kit (Qiagen, Valencia, CA, $\mathrm{USA}$ )를 사용하였다. 분리된 바이러스 배양액 중 $200 \mu \mathrm{l}$ 에 RLT buffer $550 \mu \mathrm{l}$ 를 첨가하여 섞고 실온에 5 분간 정치 한 후 $100 \%$ ethanol을 첨가한 후 전체를 섞고 vortexing 하였다. 이 시료를 spin column에 옮긴 뒤 1 분간 원심분 리 $(13000 \mathrm{rpm})$ 하였다. 세척과 건조를 한 뒤 RNase free water $40 \mu \mathrm{l}$ 로 RNA를 추출하였다.

$$
\text { RT-PCR }
$$

추출한 RNA에 primer (random hexamers), $2.5 \mathrm{mM} \mathrm{dNTP}$ 를 넣고 $70^{\circ} \mathrm{C}$ 에서 5 분간 반응한 뒤 즉각 $4{ }^{\circ} \mathrm{C}$ 에서 3 분간 정치한 뒤, Omniscript reverse transcriptase와 RT buffer를 넣 어준 뒤 $37^{\circ} \mathrm{C}$ 에서 60 분간 반응시켰다. 
Table 1. List of primers used for amplifying and sequencing of the eight viral genes

\begin{tabular}{|c|c|c|c|}
\hline Oligonucleotide & Sequence & Position & Polarity \\
\hline 'MDV-B 5' HA & TATTCGTCTCAGGGAGCAGAAGCAGAGCATTTTCTAATATC & $1 \sim 40$ & Sence \\
\hline${ }^{\mathrm{b}} \mathrm{B} \mathrm{HA} \mathrm{A}$ & GTGACTGGTGTGATACCACT & $121 \sim 140$ & Sence \\
\hline${ }^{\mathrm{b}} \mathrm{B}$ HA DII & TGTTTTCACCCATATTGGGC & $1005 \sim 1023$ & Antisense \\
\hline 'MDV-B 3' HA & ATATCGTCTCGTATTAGTAGTAACAAGAGCATTTTTC & $1719 \sim 1755$ & Antisense \\
\hline${ }^{\mathrm{a}} \mathrm{NAb}-1$ & TATTCGTCTCAGGGAGCAGAAGCAGAGCA & $1 \sim 29$ & Sence \\
\hline${ }^{\mathrm{a} N A b-1557 R}$ & ATATCGTCTCGTATTAGTAGTAACAAGAGCATTTT & $1523 \sim 1557$ & Antisense \\
\hline${ }^{\mathrm{a}} \mathrm{MDV}-\mathrm{B} 5^{\prime} \mathrm{M}$ & TATTCGTCTCAGGGAGCAGAAGCACGCACTTTCTTAAAATG & $1 \sim 41$ & Sence \\
\hline B M 560R & GTTCATAGCTGAGACCATCTG & $540 \sim 560$ & Antisense \\
\hline${ }^{\mathrm{a}} \mathrm{MDV}-\mathrm{B} 3^{\prime} \mathrm{M}$ & ATATCGTCTCGTATTAGTAGAAACAACGCACTTTTTCCAG & $1037 \sim 1076$ & Antisense \\
\hline 'MDV-B 5' NS & TATTCGTCTCAGGGAGCAGAAGCAGAGGATTTGTTTAGTC & $1 \sim 40$ & Sence \\
\hline 'MDV-B 3' NS & ATATCGTCTCGTATTAGTAGTAACAAGAGGATTTTTAT & $809 \sim 846$ & Antisense \\
\hline${ }^{\mathrm{a}} \mathrm{MDV}-\mathrm{B} 5^{\prime} \mathrm{NP}$ & TATTCGTCTCAGGGAGCAGAAGCACAGCATTTTCTTGTG & $1 \sim 39$ & Sence \\
\hline 'MDV-B 3' NP & ATATCGTCTCGTATTAGTAGAAACAACAGCATTTTTTAC & $1645 \sim 1683$ & Antisense \\
\hline${ }^{\mathrm{a}} \mathrm{PB} 1 \mathrm{~b}-1$ & TATTCGTCTCAGGGAGCAGAAGCGGAGCCTTTAAGATG & $1 \sim 38$ & Sence \\
\hline PB1b $890 \mathrm{~F}$ & GGGATCAGCATGACAGTAACA & $890 \sim 910$ & Sence \\
\hline PB1 $1560 \mathrm{R}$ & GCTGATTCATTTACTCCAGCA & $1540 \sim 1560$ & Antisense \\
\hline${ }^{\mathrm{a}} \mathrm{PB} 1 \mathrm{~b}-2369 \mathrm{R}$ & ATATCGTCTCGTATTAGTAGAAACACGAGCCTT & $2337 \sim 2369$ & Antisense \\
\hline${ }^{\mathrm{a}} \mathrm{PB} 2 \mathrm{~b}-1$ & TATTCGTCTCAGGGAGCAGAAGCGGAGCGTTTTCAAGATG & $1 \sim 40$ & Sence \\
\hline PB2 $890 \mathrm{~F}$ & AATCATGTCTGACAGCCATAG & $890 \sim 910$ & Sence \\
\hline${ }^{\mathrm{a}} \mathrm{PB} 2 \mathrm{~b}-1145 \mathrm{R}$ & TATTCGTCTCTCTCATTTTGCTCTTTTTTAATATTCCCC & $1107 \sim 1145$ & Antisense \\
\hline${ }^{\mathrm{a}} \mathrm{PB} 2 \mathrm{~b}-2396 \mathrm{R}$ & ATATCGTCTCGTATTAGTAGAAACACGAGCATT & $2364 \sim 2396$ & Antisense \\
\hline aAb-1 & TATTCGTCTCAGGGAGCAGAAGCGGTGCGTTTGA & $1 \sim 34$ & Sence \\
\hline Pab- $830 \mathrm{~F}$ & GCTACCAGAAGTTCCATATAA & $830 \sim 850$ & Sence \\
\hline aAb-1261R & TATTCGTCTCCCAGGGCCCTTTTACTTGTCAGAGTGC & $1225 \sim 1261$ & Antisense \\
\hline${ }^{\mathrm{a}} \mathrm{PAb}-2308 \mathrm{R}$ & ATATCGTCTCGTATTAGTAGAAACACGTGCATT & $2276 \sim 2308$ & Antisense \\
\hline
\end{tabular}

References : ${ }^{\mathrm{a}}$ Rescue of influenza B virus from eight plasmids (24)

${ }^{b}$ Multiplex PCR for typing and subtyping influenza and respiratory syncytial viruses (25)

cDNA에 1 unit Ex Takara Taq, $20 \mathrm{mM} \mathrm{Mg}{ }^{2+}, 2.5 \mathrm{mM}$ $\mathrm{dNTP}$ 와 B HA primer set (Table 1)로 DNA를 증폭시켰다. 증폭 반응 프로그램은 처음 $94^{\circ} \mathrm{C}$ 에서 5 분간 주형 핵산을 denaturation시키고 나서 $94^{\circ} \mathrm{C}$ 에서 30 초, $58^{\circ} \mathrm{C}$ 에서 30 초, $72^{\circ} \mathrm{C}$ 에서 60 초의 프로그램으로 30 회를 반복시킨 후 마지 막 회 다음에 $72^{\circ} \mathrm{C}$ 에서 최종 extension 10 분간 수행하였 다. 이 $\mathrm{PCR}$ 산물을 $0.8 \%$ agarose gel에 전기영동하여 확 인한 다음, 확인된 PCR 증폭산물을 Macrogen (Seoul, Korea)에 염기서열분석을 의뢰하여 확인하였다.
유전자 분석 및 계통 분석

Sequencing 결과로 확인된 유전자 서열을 Lasergene sequence analysis software package (DNASTAR) 프로그램을 이용하여 분석하였고, 분석한 유전자 서열과 NCBI GenBank에 등록되어 있는 최근 인플루엔자 백신 주와 세계 여러 지역에서 분리된 균주들의 유전자 서열을 추가하여 CLUSTAL_V 프로그램으로 8개 유전자에 대한 phylogenetic tree와 상대 비율의 bootstrap 값을 구하였다. 만들 어진 trees는 NJ Plot (neighbor-joining algorithm and further plotted)으로 상대적 형태에 맞게 변형하였다. 


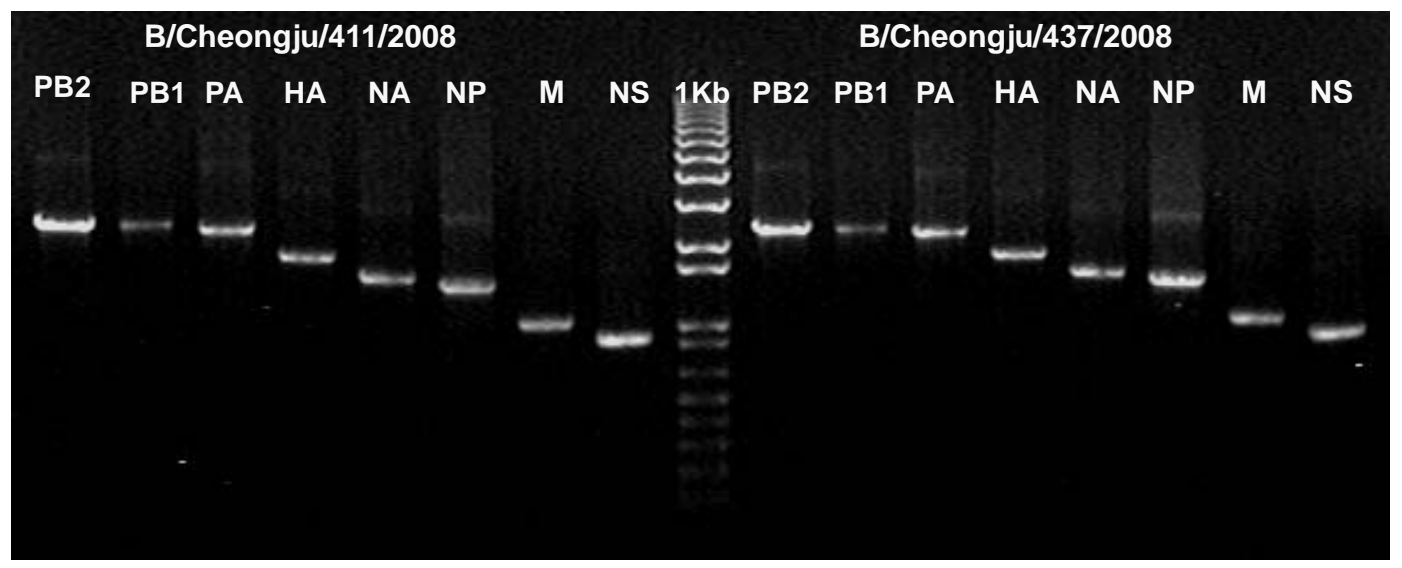

Figure 1. Amplification of the eight viral gene segments of influenza B viruses isolated in this study. Full length segments were amplified by RT-PCR using different combination of primers for each gene (Table 1) and visualized by electrophoresis on $0.8 \%$ agarose gel. Two representative viruses $(\mathrm{B} /$ Cheongju/411/2008 and B/Cheongju/437/2008 with GenBank accession number FJ461674 FJ461689) are shown (PB2: 2396 bp; PB1: 2369 bp; PA: 2308 bp; HA: 1755 bp; NP: 1683 bp; NA: 1557 bp; M: 1076 bp; NS: 846 bp).

\section{결 과}

\section{$\mathrm{B}$ 형 인플루엔자 바이러스의 분리}

국내에서 유행하는 B형 인플루엔자 바이러스의 유전 적 특징을 연구하기 위하여 2007년 6월부터 2008년 6월 까지 생후 90 일부터 14 년된 환아들 중 인플루엔자 감염 이 의심되는 환아들의 비강에서 비흡인물을 채취하였다. 총 510개 검체를 $\mathrm{MDCK}$ 세포에 감염시킨 후 48시간 동 안 $\mathrm{CO}_{2}$ 배양기에서 배양하면서, 세포병변효과와 $0.5 \%$ 닭 의 적혈구를 이용한 혈구응집검사를 수행하였다. $\mathrm{MDCK}$ 세포에 감염시킨 검체 중 총 36 개에서 혈구응집양성을 보였으며, 이 시료들로부터 RNA를 추출 후 준비된 인플 루엔자 primer set를 이용하여 RT-PCR을 시행한 바, 12 개 의 검체에서 $\mathrm{B}$ 형의 인플루엔자 바이러스가 검출되었다. 분리된 B형 인플루엔자 바이러스의 계통적 특징 및 유 전적 변이를 연구하기 위하여 각 월별 분리 바이러스를 선별하여 실험을 시행하였다. 본 연구기간 동안에 분리 된 5 개 바이러스들의 $\mathrm{HA}$ 유전자 분석결과, 이들 바이러 스의 유전자가 서로 매우 유사하여 (99.9 100\%), 이 중 두 개의 바이러스 (B/Cheongju/411/08와 B/Cheongju/437/ 08 )를 선택하여 전체 8 개의 유전자 분석을 수행하여, 각 연도별 백신 균주 및 이전에 국내에서 분리된 분리주들 과 비교 분석하였다 (Fig. 1).
$\mathrm{B}$ 형 인플루엔자 바이러스의 계통발생학적 분석

본 연구에서 분리한 $\mathrm{B}$ 형 인플루엔자 바이러스들의 유 전적 기원을 알아보기 위해 8 개의 각 유전자들을 인플루 엔자 B 바이러스의 두 계통인 Victoria lineage와 Yamagata lineage를 중심으로 하여 최근의 백신 균주와 세계 여러 지역에서 분리된 다른 균주들과 함께 비교 분석하여 보 았다. 먼저 인플루엔자 바이러스의 표면항원으로서 세포 막의 수용체와 결합하여 바이러스를 체세포에 부착하는 $\mathrm{HA}$ 유전자와 바이러스의 방출에 관여하는 NA 유전자의 유전자 계통을 분석한 결과, 충정북도 청주지역에서 분 리된 B/Cheongju/411/08 그리고 B/Cheongju/437/08의 HA, $\mathrm{NA}$ 유전자 모두 두 계통 중 Yamagata lineage에 해당함 을 알 수 있었다 (Fig. 2A, 2B). 이 결과는 2007 2008년 우리나라를 포함한 북반구에서 사용된 백신 strain B/ Malaysia/2506/04 (Victoria lineage)과 전혀 다른 Yamagata lineage 기원의 바이러스가 국내에서 유행하였음을 보여 주는 중요한 결과라 할 수 있다.

더불어 polymerase 유전자 (PB2, PB1, PA)를 포함한 $\mathrm{NP}$, $\mathrm{M}, \mathrm{NS}$ 의 유전자도 $\mathrm{HA}, \mathrm{NA}$ 유전자와 같은 방법으로 두 개의 lineage를 중심으로 최근의 백신 균주와 세계 여 러 지역에서 분리된 다른 균주들과 함께 비교 분석한 결과, NS 유전자를 제외한 나머지 5 개의 internal 유전자 들의 유전적 기원은 $\mathrm{HA}$ 와 $\mathrm{NA}$ 유전자와 마찬가지로 모 두 2007 2008년 우리나라를 포함한 북반구에서 사용된 백신 균주인 Victoria lineage가 아닌 Yamagata lineage에 해 
A $\mathrm{HA}$

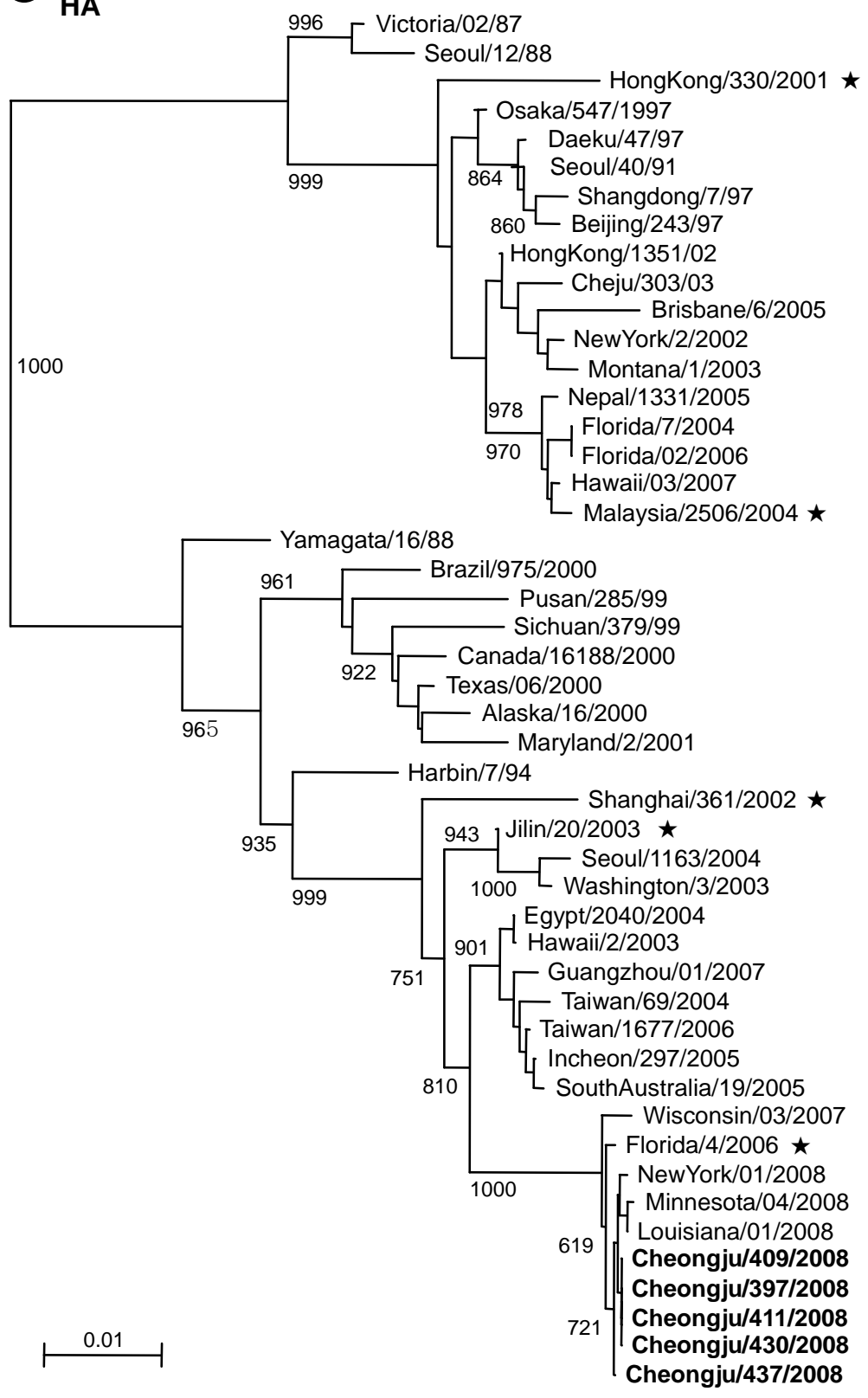

B NA

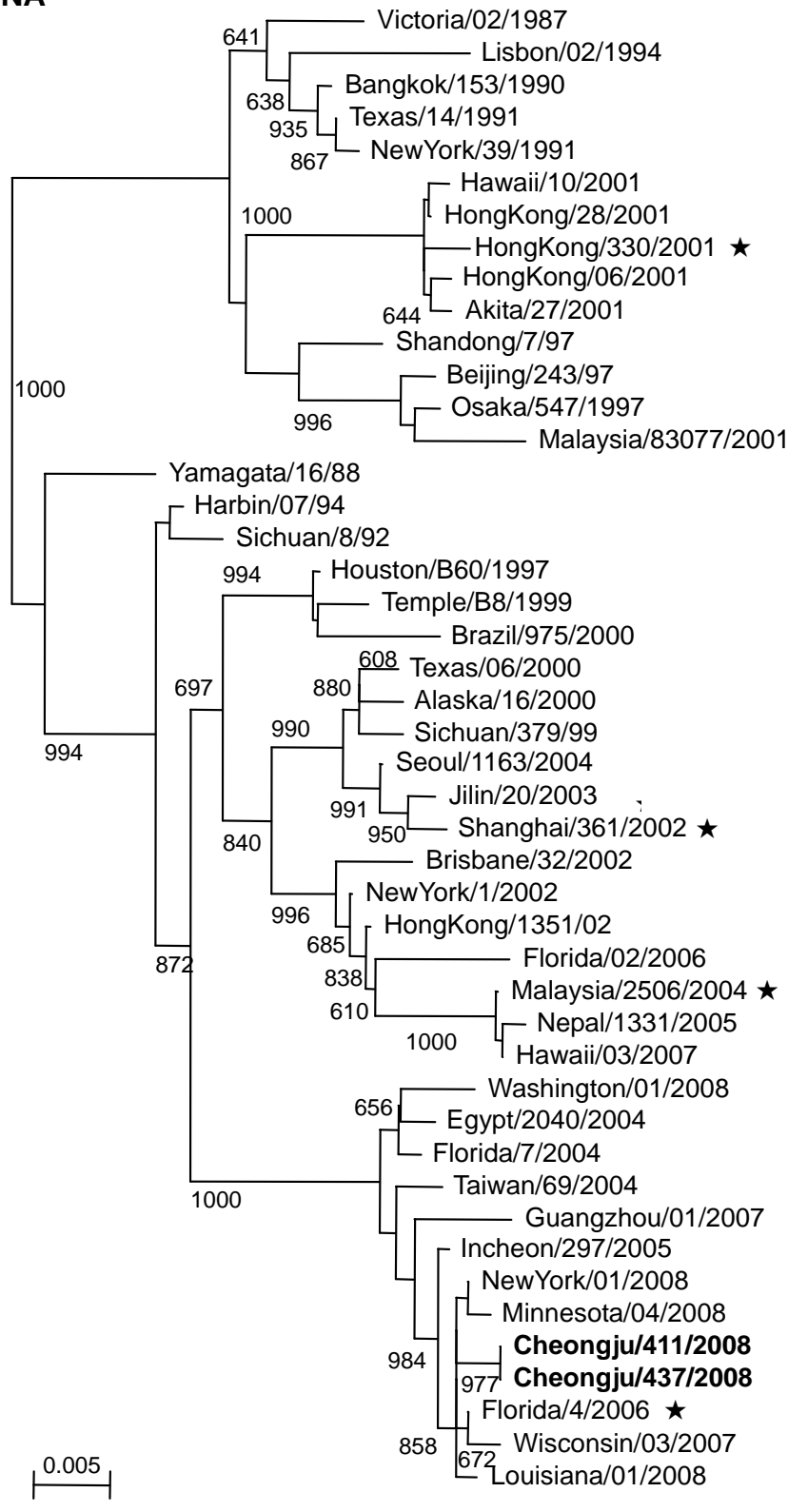


C NS

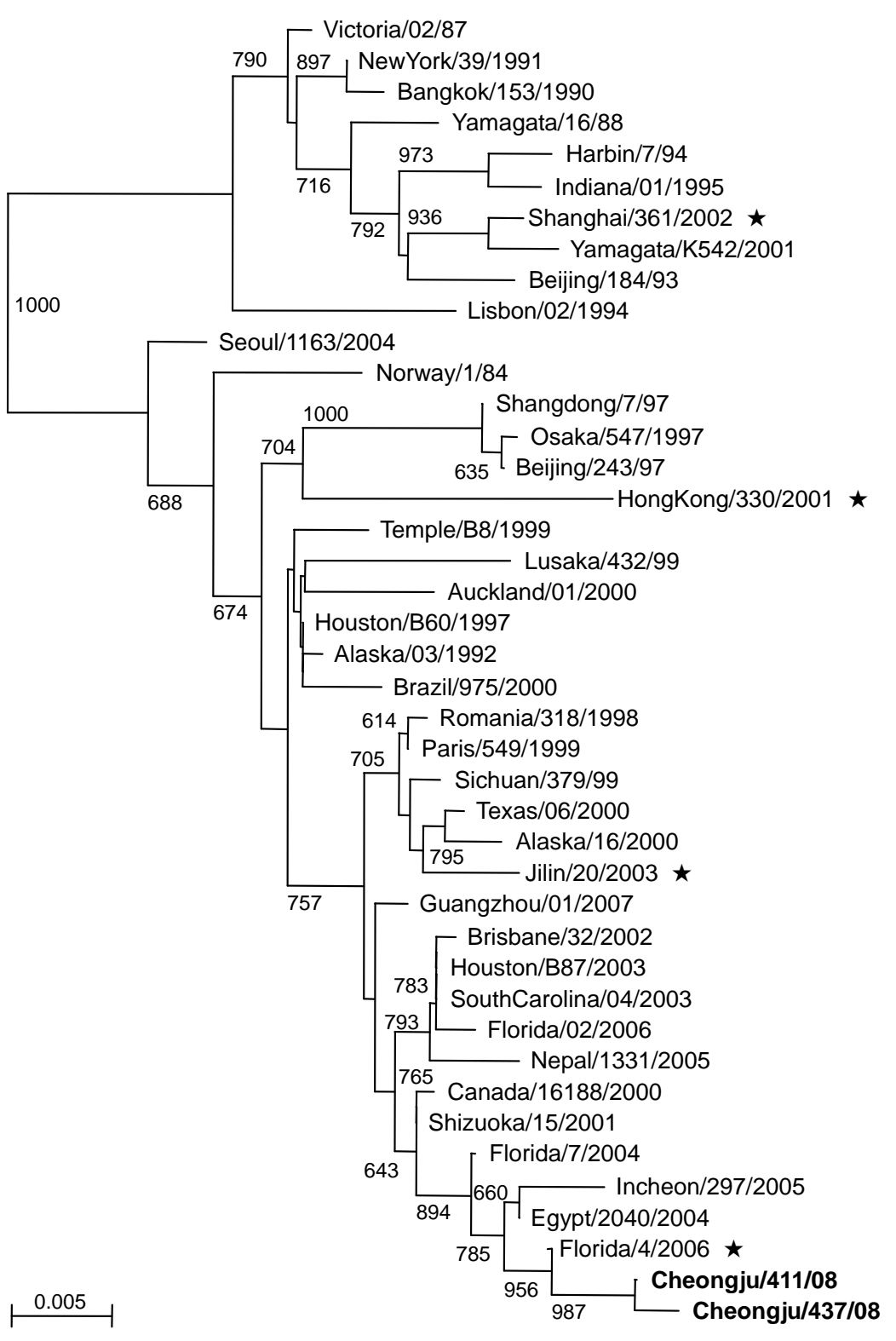

(D) $M$

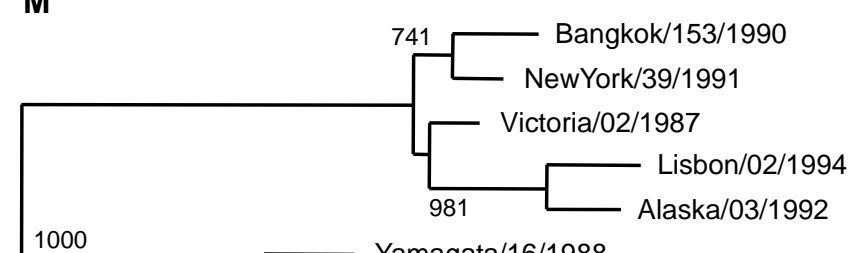

1000

Yamagata/16/1988

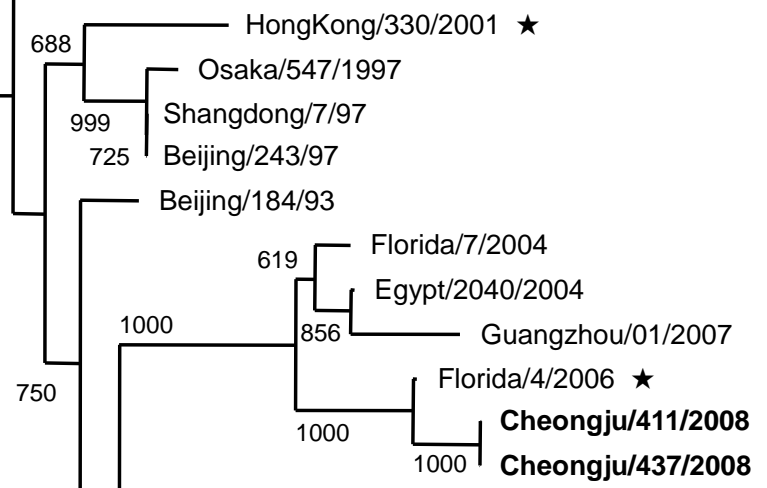


E $\mathrm{NP}$

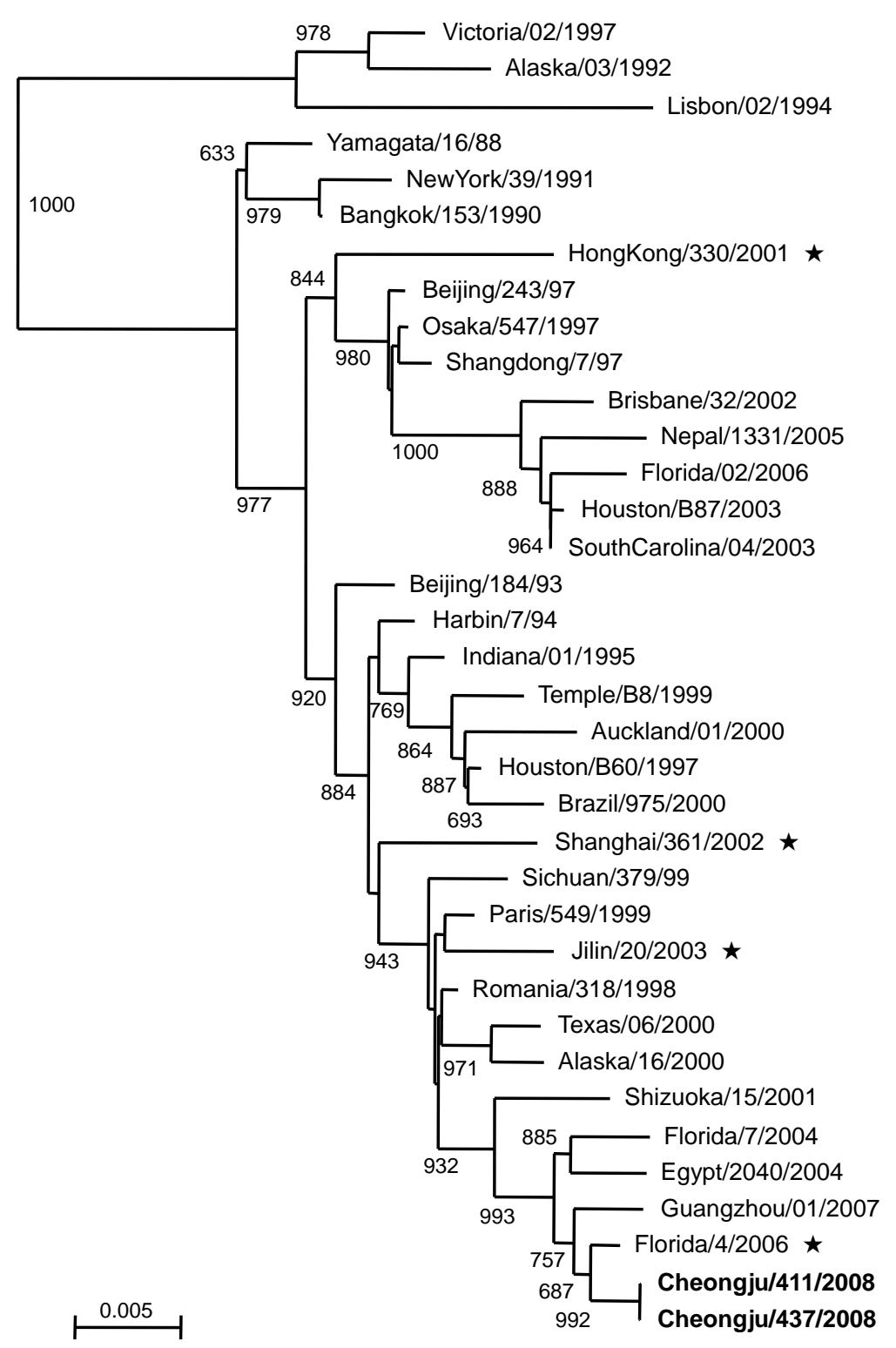

F PA

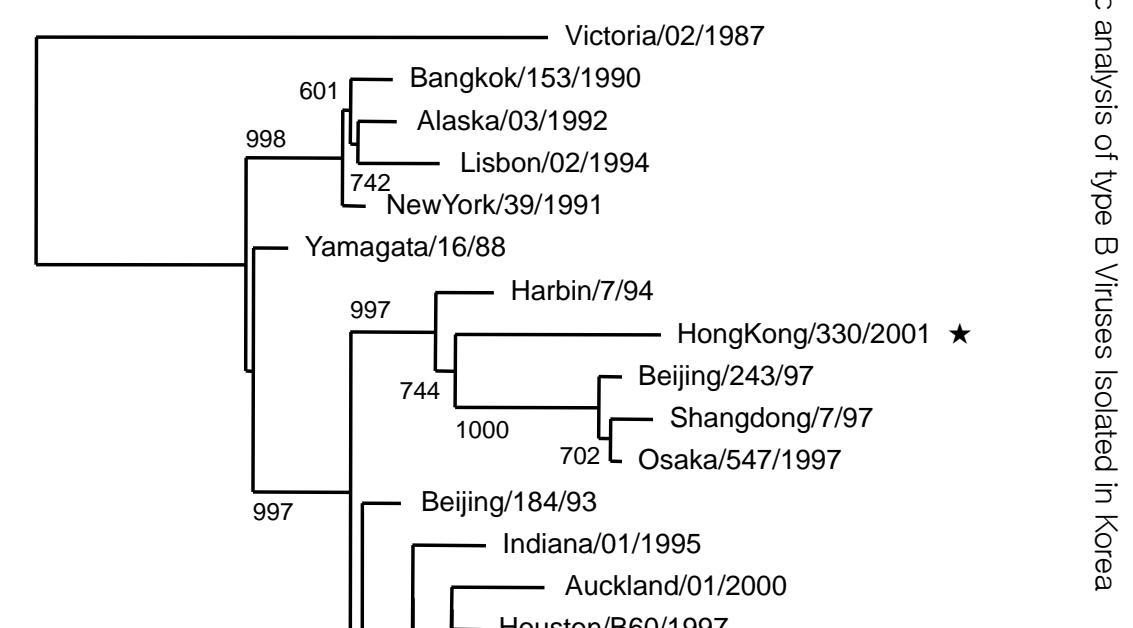




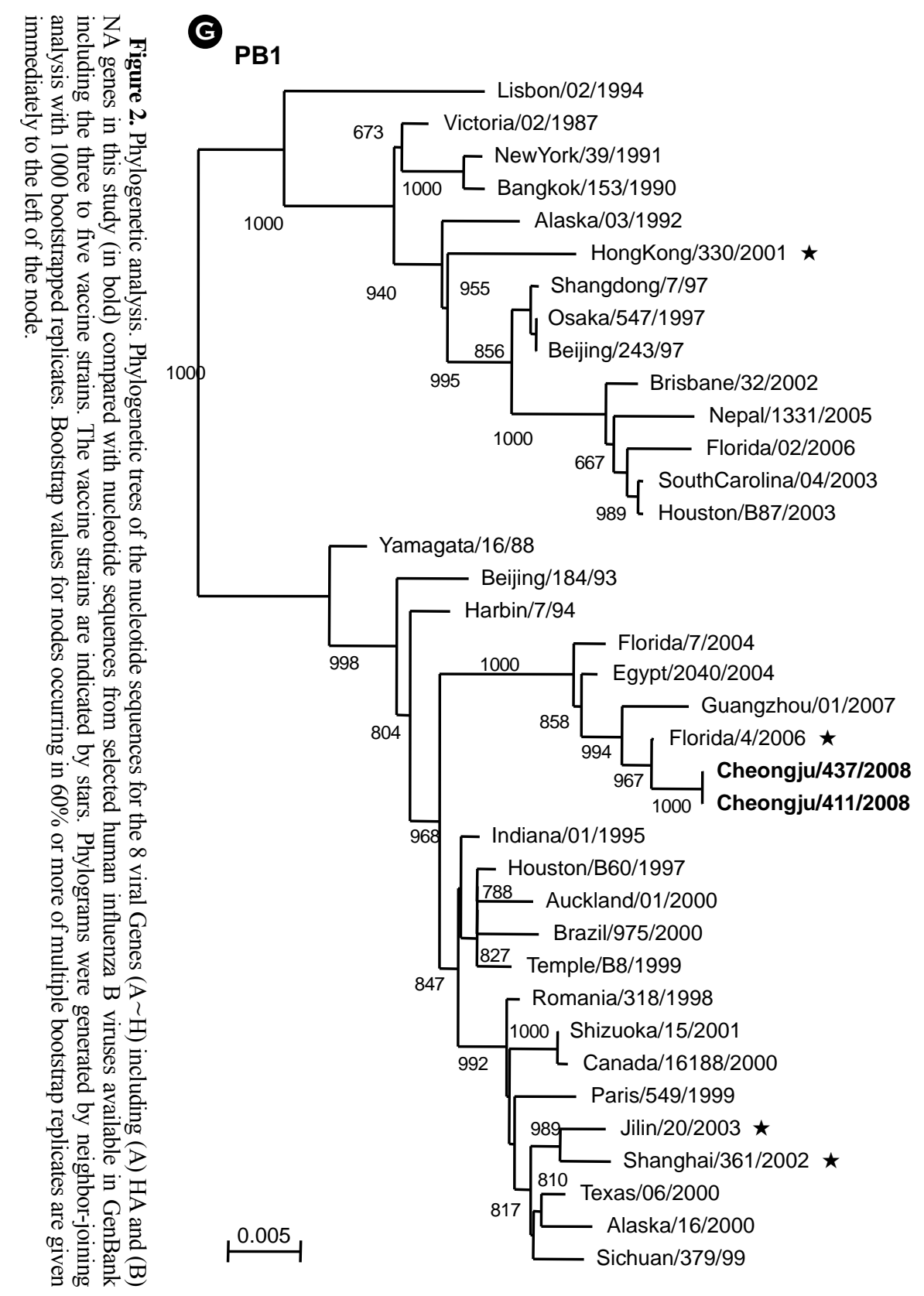

(H)

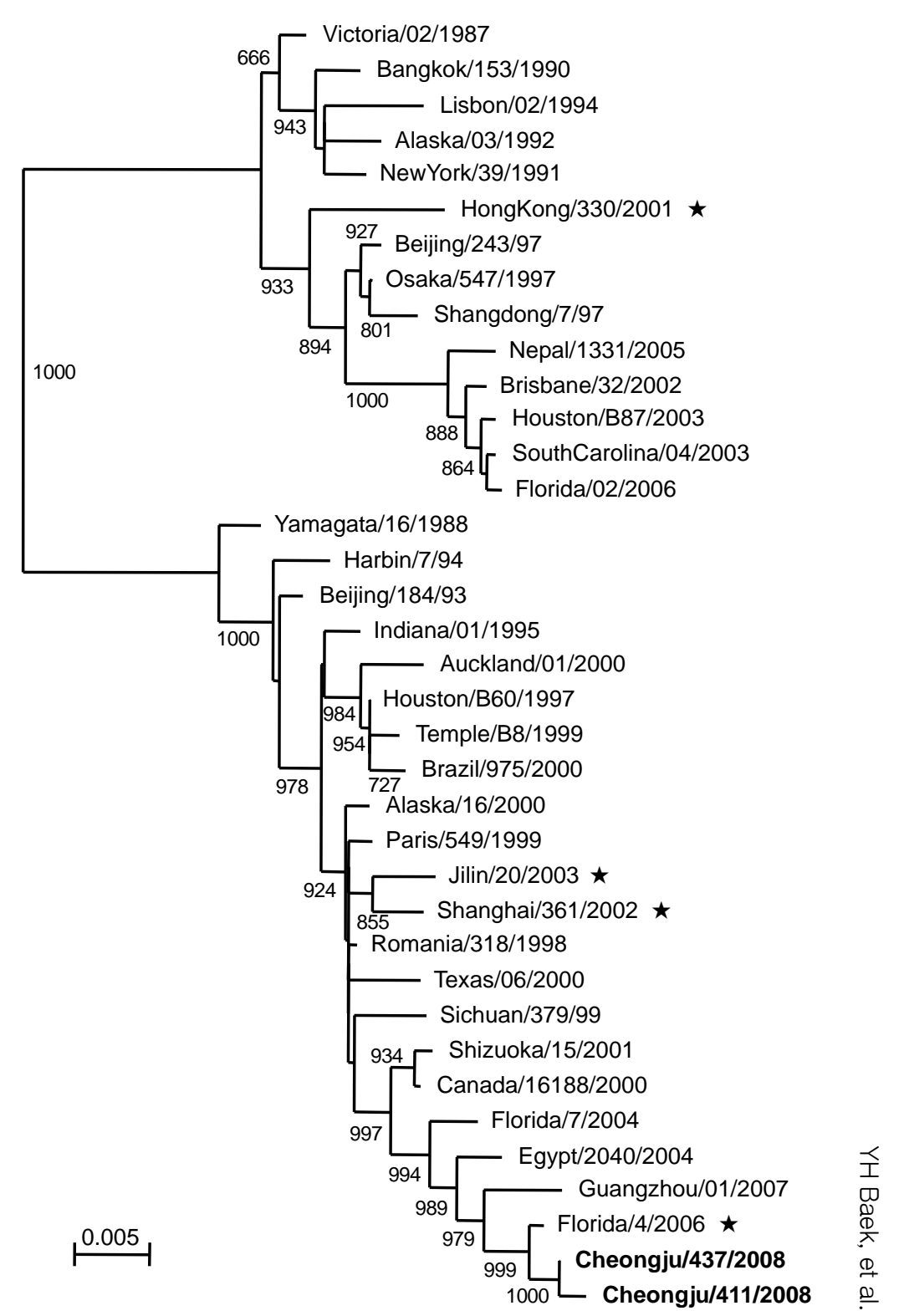


당함을 알 수 있었다 (Fig. 2D H). 하지만 NS 유전자는 Victoria/Yamagata lineage에 해당되지 않고 새로운 B/ Norway $/ 1 / 84$ 를 기준으로 분류되는 lineage에 해당하는 특 징을 확인할 수 있었다 (Fig. 2C)

B형 인플루엔자 바이러스 HA 1과 NA 아미노산 서열의 변이

본 연구에서 분리된 $\mathrm{B}$ 형 인플루엔자 바이러스의 유전 적 특징을 알아보기 위하여 GenBank에 저장된 기분리주 들과 비교 관찰한 결과 $\mathrm{B} /$ Cheongju/411/08 바이러스의 $\mathrm{HA}$ 유전자는 같은 해 뉴욕에서 분리된 B/New York/01/ 2008 바이러스와 가장 유사하였으며 (핵산 상동율 $99 \%$, 아미노산 상동율 99.8\%), B/Cheongju/437/08 바이러스의 $\mathrm{HA}$ 유전자는 2006년 미국 플로리다 주에서 분리된 B/ Florida/4/2006 바이러스와 매우 높은 유전자 상동율 (핵 산 상동율 $99.8 \%$, 아미노산 상동율 $99.8 \%$ )을 보였다.

HA 유전자의 변이율을 알아 보기 위하여 2004 2006 년 북반구에서 사용되었던 백신 균주 (B/Shanghai/361/02
$\mathrm{B} / \mathrm{Jilin} / 20 / 03$ )와 2007 2008년 우리나라를 포함한 북반구 에서 사용된 백신 균주 (B/Malaysia/2506/04)를 국내 바 이러스와 비교 분석해 보았다. 가장 먼저 유전적 변이 율이 가장 높은 HA1 부위에서 많은 변이가 관찰되었다 (Table 2). 특히 23개의 변이 중 40, 230, 252 아미노산 부 위에서의 변이는 아직까지 다른 바이러스들에서는 나타 나지 않았던 국내 바이러스 특이의 소변이 (antigenic drift)임이 확인되었다 (H40Y, D/G230S, V252M). 또한 196 부위에서는 aspartic acid에서 asparagine (D196N)으로의 변 이에 의해 B/Yamagata/16/88와 B/Shanghai/361/02에는 존 재하지 않던 N-glycosylation 부위가 B/Malaysia/2506/04 와 함께 지속적으로 유지됨을 관찰할 수 있었다.

다음으로 NA 유전자 분석결과 총 30 개의 유전자 변이 중 11 개의 부위에서 아직까지 다른 바이러스들에서는 나 타나지 않았던 국내 바이러스 특이의 소변이가 일어났 음을 확인하였다 (P3H, P/T/S42Q, K/T49I, N59S, T68A, K125T, N219K, S244P, D329N, N340D, D392E).

이상의 유전자 분석결과는 2007 2008년 충청북도 청

Table 2. Amino acid variations of HA 1 region from Influenza B isolates in Cheongju, Korea compared with B/Yamagata/16/88

\begin{tabular}{|c|c|c|c|c|c|c|c|c|c|c|c|c|c|}
\hline \multirow{2}{*}{ Virus strain(s) } & \multicolumn{13}{|c|}{ Amino acid at position } \\
\hline & 37 & 40 & 48 & 56 & 73 & 76 & 122 & 126 & 129 & 131 & 146 & 149 & 150 \\
\hline B/Yamagata/16/88 & $\mathrm{T}$ & $\mathrm{H}$ & $\mathrm{K}$ & $\mathrm{N}$ & M & I & $\mathrm{H}$ & $\mathrm{N}$ & $\mathrm{R}$ & $\mathrm{P}$ & $\mathrm{V}$ & $\mathrm{R}$ & $\mathrm{N}$ \\
\hline B/Shanghai $/ 361 / 02^{\mathrm{a}}$ & I & $\cdot$ & $\mathrm{R}$ & $\mathrm{D}$ & $\mathrm{V}$ & $\mathrm{T}$ & Q & $\mathrm{D}$ & $\mathrm{K}$ & $\mathrm{L}$ & A & K & $\mathrm{S}$ \\
\hline B/New york/01/08 & $\cdot$ & $\mathrm{Y}$ & $\mathrm{R}$ & $\mathrm{D}$ & $\mathrm{V}$ & $\mathrm{T}$ & Q & $\mathrm{D}$ & $\mathrm{K}$ & $\cdot$ & A & K & $\mathrm{S}$ \\
\hline B/Cheongju/411/08 & $\cdot$ & $\mathrm{Y}$ & $\mathrm{R}$ & $\mathrm{D}$ & $\mathrm{V}$ & $\mathrm{T}$ & Q & $\mathrm{D}$ & $\mathrm{K}$ & $\cdot$ & A & K & $\mathrm{S}$ \\
\hline B/Cheongju/437/08 & $\cdot$ & $\mathrm{Y}$ & $\mathrm{R}$ & $\mathrm{D}$ & $\mathrm{V}$ & $\mathrm{T}$ & Q & $\mathrm{D}$ & $\mathrm{K}$ & $\cdot$ & A & K & $\mathrm{S}$ \\
\hline B/Malaysia/2506/04 & $\cdot$ & $\cdot$ & $\cdot$ & $\cdot$ & $\mathrm{T}$ & $\cdot$ & . & . & $\mathrm{N}$ & $\cdot$ & . & G & $\cdot$ \\
\hline
\end{tabular}

\begin{tabular}{lccccccccccccc}
\hline & \multicolumn{1}{c}{ Amino acid position } & \multicolumn{4}{c}{ Glycosylation } \\
\cline { 2 - 11 } Virus strain(s) & 162 & 165 & 168 & 183 & 197 & 230 & 233 & 252 & 272 & 320 & $196 \sim 198$ \\
\hline B/Yamagata/16/88 & $\mathrm{R}$ & - & $\mathrm{T}$ & $\mathrm{K}$ & $\mathrm{D}$ & $\mathrm{D}$ & $\mathrm{N}$ & $\mathrm{V}$ & $\mathrm{K}$ & $\mathrm{N}$ & $\mathrm{DKT}(-)$ \\
B/Shanghai/361/02 & $\mathrm{K}$ & $\mathrm{N}$ & $\mathrm{N}$ & $\mathrm{E}$ & $\cdot$ & $\mathrm{G}$ & $\mathrm{D}$ & $\cdot$ & $\cdot$ & $\mathrm{H}$ & $\mathrm{DKT}(-)$ \\
B/New york/01/08 & $\mathrm{K}$ & $\mathrm{N}$ & $\mathrm{N}$ & $\mathrm{E}$ & $\mathrm{N}$ & $\mathrm{S}$ & $\mathrm{D}$ & $\mathrm{M}$ & $\mathrm{R}$ & $\mathrm{H}$ & $\mathrm{NKT}(+)$ \\
B/Cheongju/411/08 & $\mathrm{K}$ & $\mathrm{N}$ & $\mathrm{N}$ & $\mathrm{E}$ & $\mathrm{N}$ & $\mathrm{S}$ & $\mathrm{D}$ & $\mathrm{M}$ & $\mathrm{R}$ & $\mathrm{H}$ & $\mathrm{NKT}(+)$ \\
B/Cheongju/437/08 & $\mathrm{K}$ & $\mathrm{N}$ & $\mathrm{N}$ & $\mathrm{E}$ & $\mathrm{N}$ & $\mathrm{S}$ & $\mathrm{D}$ & $\mathrm{M}$ & $\cdot$ & $\mathrm{H}$ & $\mathrm{NKT}(+)$ \\
B/Malaysia/2506/04 & $\mathrm{K}$ & $\mathrm{N}$ & $\mathrm{N}$ & $\mathrm{E}$ & $\mathrm{N}$ & $\cdot$ & $\mathrm{N}$ & $\cdot$ & $\cdot$ & $\cdot$ & $\mathrm{NKT}(+)$ \\
\hline
\end{tabular}

The strain (B/Yamagata/16/88) was used as a reference for comparison. The amino acid substitution in different sites is shown. Dots represent amino acid similar to the reference strain while the dash denotes deletion. Shaded amino acids indicate identical residues at these sites with $\mathrm{B} / \mathrm{New}$ york $/ 01 / 08$ compared to the reference isolate and vaccine strains.

a 2004 2006 vaccine strain, ${ }^{b} 2007 \sim 2008$ vaccine strain 
Table 3. Amino acid variations of NA region from Influenza B isolates in Cheongju, Korea compared with B/Yamagata/16/88

\begin{tabular}{|c|c|c|c|c|c|c|c|c|c|c|c|c|c|c|c|}
\hline \multirow{2}{*}{ Virus strain(s) } & \multicolumn{15}{|c|}{ Amino acid at position } \\
\hline & 3 & 42 & 49 & 50 & 59 & 68 & 71 & 76 & 88 & 107 & 125 & 186 & 193 & 202 & 219 \\
\hline B/Yamagata/16/88 & $\mathrm{P}$ & $\mathrm{P}$ & $\mathrm{K}$ & $\mathrm{V}$ & $\mathrm{N}$ & $\mathrm{T}$ & M & $\mathrm{S}$ & Q & $\mathrm{R}$ & $\mathrm{K}$ & $\mathrm{R}$ & $\mathrm{L}$ & I & $\mathrm{N}$ \\
\hline B/Shanghai/361/02 ${ }^{\mathrm{a}}$ & $\cdot$ & $\mathrm{T}$ & $\mathrm{T}$ & $\mathrm{M}$ & $\cdot$ & $\cdot$ & $\mathrm{V}$ & $\mathrm{P}$ & $\mathrm{P}$ & K & K & K & V & $\mathrm{L}$ & - \\
\hline B/New york/01/08 & $\cdot$ & Q & I & $\mathrm{M}$ & $\cdot$ & A & $\mathrm{V}$ & $\mathrm{P}$ & $\mathrm{P}$ & $\mathrm{K}$ & $\mathrm{T}$ & K & $\mathrm{V}$ & $\mathrm{L}$ & K \\
\hline B/Cheongju/411/08 & $\mathrm{H}$ & Q & I & $\mathrm{M}$ & $\mathrm{S}$ & A & $\mathrm{V}$ & $\mathrm{P}$ & $\mathrm{P}$ & $\mathrm{K}$ & $\mathrm{T}$ & K & $\mathrm{V}$ & $\mathrm{L}$ & K \\
\hline B/Cheongju/437/08 & $\mathrm{H}$ & Q & I & M & $\mathrm{S}$ & A & $\mathrm{V}$ & $\mathrm{P}$ & $\mathrm{P}$ & $\mathrm{K}$ & $\mathrm{T}$ & K & $\mathrm{V}$ & $\mathrm{L}$ & K \\
\hline B/Malaysia/2506/04 & . & $\mathrm{S}$ & $\mathrm{T}$ & M & $\cdot$ & $\cdot$ & $\mathrm{V}$ & . & $\mathrm{P}$ & $\mathrm{K}$ & K & . & . & . & - \\
\hline
\end{tabular}

\begin{tabular}{|c|c|c|c|c|c|c|c|c|c|c|c|c|c|c|c|}
\hline \multirow{2}{*}{ Virus strain(s) } & \multicolumn{15}{|c|}{ Amino acid at position } \\
\hline & 235 & 244 & 250 & 272 & 329 & 340 & 342 & 345 & 373 & 378 & 389 & 392 & 396 & 404 & 436 \\
\hline B/Yamagata/16/88 & $\mathrm{D}$ & S & K & $\mathrm{E}$ & $\mathrm{D}$ & $\mathrm{N}$ & $\mathrm{D}$ & $\mathrm{R}$ & $\mathrm{E}$ & $\mathrm{E}$ & $\mathrm{T}$ & $\mathrm{D}$ & $\mathrm{P}$ & $\mathrm{K}$ & $\mathrm{E}$ \\
\hline B/Shanghai/361/02 ${ }^{\mathrm{a}}$ & $\mathrm{N}$ & . & E & K & - & $\mathrm{N}$ & $\mathrm{N}$ & S & K & G & I & . & - & $\mathrm{E}$ & $\mathrm{T}$ \\
\hline B/New york/01/08 & . & $\mathrm{P}$ & $\mathrm{E}$ & $\mathrm{K}$ & $\mathrm{N}$ & $\mathrm{D}$ & - & $\mathrm{S}$ & $\mathrm{K}$ & G & · & . & - & $\mathrm{E}$ & $\mathrm{T}$ \\
\hline B/Cheongju/411/08 & . & $\mathrm{P}$ & $\mathrm{E}$ & K & $\mathrm{N}$ & $\mathrm{D}$ & . & S & K & G & · & $\mathrm{E}$ & - & $\mathrm{E}$ & $\mathrm{T}$ \\
\hline B/Cheongju/437/08 & · & $\mathrm{P}$ & $\mathrm{E}$ & $\mathrm{K}$ & $\mathrm{N}$ & $\mathrm{D}$ & · & $\mathrm{S}$ & $\mathrm{K}$ & G & · & $\mathrm{E}$ & $\cdot$ & $\mathrm{E}$ & $\mathrm{T}$ \\
\hline B/Malaysia/2506/04 & $\mathrm{N}$ & $\cdot$ & $\mathrm{E}$ & $\mathrm{K}$ & $\cdot$ & $\mathrm{N}$ & . & . & . & G & A & . & $\mathrm{F}$ & $\mathrm{E}$ & $\cdot$ \\
\hline
\end{tabular}

The strain (B/Yamagata/16/88) was used as a reference for comparison. The amino acid substitution in different sites is shown. Dots represent amino acid similar to the reference strain while the dash denotes deletion. Shaded amino acids indicate identical residues at these sites with $\mathrm{B} / \mathrm{New}$ york/01/08 compared to the reference isolate and vaccine strains.

${ }^{a}$ 2004 2006 vaccine strain, ${ }^{b} 2007 \sim 2008$ vaccine strain

주지역에서 분리된 B형 인플루엔자 바이러스는 같은 해 국내에서 사용되었던 백신 균주 (B/Victoria/2/87 lineage) 와는 전혀 상이한 B/Yamagata/16/88 lineage의 바이러스로 판명이 되었으며, B/Yamagata/16/88 lineage의 바이러스들 과의 비교에서도 다수의 특이 항원소변이 (antigenic drift) 가 일어 났음을 보여주고 있다 (Table 2,3).

\section{Internal 유전자의 변이}

B/Cheongju/411/08 그리고 B/Cheongju/437/08 바이러스 들의 $\mathrm{HA}$ 유전자를 제외한 다른 7 개의 유전자에서는 모 두 2006년 미국의 플로리다 주에서 분리된 B/Florida/4/ 2006과 가장 높은 상동율을 보였다. NS 유전자는 99.4 $99.6 \%, \mathrm{~PB} 2$ 유전자의 경우 99.1 99.6\%, NA, M, NP 유전 자들에서는 $99.6 \%$, 특히 바이러스 증식에 관련하는 polymerase 유전자인 PB1, 그리고 PA 유전자에서는 아미노산 상동율 $99.9 \%$ 로 B/Florida/4/2006 바이러스와 매우 높은 유전자 상동율을 나타내었다. 따라서 본 연구기간 동안 충청북도 청주지역에서 분리된 바이러스 중 $\mathrm{B} /$ Cheongju/
411/08 바이러스의 HA 유전자를 제외한 모든 유전자들 이 2006년 북미에서 분리된 B/Florida/4/2006 바이러스와 매우 유사하였다 (Fig. 2C H).

\section{고 찰}

2007년 6월부터 2008년 6월까지 충청북도 청주지역의 소아과병원에서 호흡기질환으로 내원한 소아의 인두를 멸균된 면봉으로 도말하여 검체를 채취하여 $\mathrm{B}$ 형 인플루 엔자 바이러스의 감염양상 및 유전적 특징을 분석하였다. 채취된 시기 중 인플루엔자 B 바이러스는 2008년 2월에 12 개중 5 개의 가장 많은 양성 검체가 확인되었다. 이는 질병관리본부 전염병 감시팀에서 인플루엔자 바이러스의 주간 별 분리현황 발표내용 중 2008년 2월에 인플루엔자 $\mathrm{B}$ 바이러스 감염이 전체 인플루엔자 감염 중 $80 \%$ 가 넘 는 높은 양성율을 보였다는 분리현황보고와 일치하는 연 구결과였다 (19).

세계 여러 지역에서 분리된 인플루엔자 $\mathrm{B}$ 바이러스는 
항원과 유전적 특성에 의해 B/Victoria/2/87와 B/Yamagata/ $16 / 88$ 두 계통으로 구분된다 $(1,4,10,11,20,21)$. 본 연구 기간에 분리된 $\mathrm{B}$ 형 인플루엔자 바이러스의 유전자 계통 을 비교 분석한 결과, 2007 2008년에 청주지역에서 분리 된 바이러스는 2007 2008 국내에서 백신 균주로 사용되 었던 B/Malaysia/2506/04가 속해 있는 Victoria lineage가 아닌 2004 2005년 북반구에서 사용한 백신 균주인 B/ Shanghai/361/02, B/Jilin/20/03가 속해 있는 Yamagata lineage 에 속해 있음을 확인할 수 있었다. 또한 HA와 NA를 포 함하여 다른 internal 유전자들 모두 phylogenetic tree를 분석한 결과, 항원재배열 등으로 인한 다양한 lineage를 가지고 있는 NS 유전자를 제외한 (22) 7개 유전자들은 모두 Yamagata lineage에 속하는 것을 확인할 수 있었다.

질병관리본부에서 2008년 9월 5일 발표한 표본감시 결과에 의하면 인플루엔자 B 바이러스는 2000 2001, 2002 2003년에는 1건도 분리· 보고되지 않았으며, 이후 2007년까지 A 바이러스 (H1N1, H3N2) 분리율에 비하여 상대적으로 낮은 분리율을 나타내었다. 하지만 2007 2008년에는 전체 인플루엔자 바이러스 분리건 수 4,641 중, 2,976건 (64.1\%)이 B형으로 판명됨에 따라 최근 7 8 년 중 B 바이러스의 가장 많은 분리율을 나타내었다 (19). 이는 2007 2008년 한국을 포함한 북반구 백신 균주인 B/Malaysia/2506/2004는 Victoria lineage인에 반면, 우리나 라에서 유행, 분리된 바이러스는 2007 2008 백신 균주와 는 다른 Yamagata lineage에 해당하는 결과를 통해 2007 2008년 A형에 비해 B 바이러스 감염 및 분리율이 다른 해보다 유난히 높았던 이유를 짐작할 수 있게 한다.

인플루엔자 B 바이러스는 $\mathrm{A}$ 바이러스에 비해 사망률 자체가 높지 않다고 여겨지지만, 발생되는 지역, 규모가 방대하기 때문에 항원의 변이와 재배열된 바이러스가 새 로운 유행을 만들어 낼 때에는 기존보다 더 막대한 인명 피해와 사회의 경제적 손실을 일으킬 수도 있다 (23). 그 러므로 이상적인 인플루엔자 백신의 사용은 여러 가지 항원형에 효과가 있어야 하며 대유행 이전 또는 대유행 사이 기간에도 사용할 수 있어야 한다. 그러나 바이러스 유전자의 재조합과 재배열에 의한 항원적 변이가 빈번할 수 있는 인플루엔자 바이러스의 특성은 숙주의 면역적인 방어능력을 저하시키고, 인플루엔자 바이러스의 백신개발 과 사용을 어렵게 할 수 있다. 따라서 국내의 $\mathrm{A}$ 형 인플 루엔자 바이러스뿐만 아니라 B형 인플루엔자 바이러스 에 대한 지속적인 감시와 유전자의 비교 분석 등의 연구
는 항원의 변이에 의한 새로운 바이러스 유행형을 예측 하고, 이에 적절한 백신 균주의 사용 계획방안 수립 등에 중요한 자료로 활용될 수 있을 것으로 판단된다.

\section{참 고 문 헌}

1) Jian JW, Lai CT, Kuo CY, Kuo SH, Hsu LC, Chen PJ, Wu HS, Liu MT. Genetic analysis and evaluation of the reassortment of influenza B viruses isolated in Taiwan during the 2004 2005 and 2006 2007 epidemics. Virus Res 2008;131:243-9.

2) Wright PF, Webster RG. Orthomyxoviruses. In: K.D.M. Fields and B.N. Hawley, Editors, Virology, Lippencott-Raven, Philadelphia 2001; pp. 1533-79.

3) Mitnaul LJ, Matrosovich MN, Castrucci MR, Tuzikov AB, Bovin NV, Kobasa D, Kawaoka Y. Balanced hemagglutinin and neuraminidase activities are critical for efficient replication of influenza A virus. J Virol 2000;74:6015-20.

4) Rota PA, Wallis,TR, Harmon MW, Rota JS, Kendal AP, Nerome K. Cocirculation of two distinct evolutionary lineages of influenza type B virus since 1983. Virology 1990;175:5968.

5) $\mathrm{Xu} X$, Lindstrom SE, Shaw MW, Smith CB, Hall HE, Mungall BA, Subbarao K, Cox NJ, Klimov A. Reassortment and evolution of current human influenza A and B viruses. Virus Res 2004;103:55-60.

6) Betakova T, Nermut MV, Hay AJ. The NB protein is an integral component of the membrane of influenza B virus. J Gen Virol 1996;77:2689-94.

7) Brassard DL, Leser GP, Lamb RA. Influenza B virus NB glycoprotein is a component of the virion. Virology 1996;220: $350-60$.

8) Briedis DJ and Tobin M. Influenza B virus genome: complete nucleotide sequence of the influenza $\mathrm{B} / \mathrm{Lee} / 40$ virus genome RNA segment 5 encoding the nucleoprotein and comparison with the B/Singapore/222/79 nucleoprotein. Virology 1984; 133:448-55.

9) Briedis DJ, Lamb RA, Choppin PW. Sequence of RNA segment 7 of the influenza B virus genome: partial amino acid homology between the membrane proteins (M1) of influenza A and B viruses and conservation of a second open reading frame. Virology 1982;116:581-8.

10) Kanegae Y, Sugita S, Endo A, Ishida M, Senya S, Osako K, Nerome K, Oya A. Evolutionary pattern of the hemagglutinin 
gene of influenza B viruses isolated in Japan: cocirculating lineages in the same epidemic season. J Virol 1990;64:28605.

11) Rota PA, Hemphill ML, Whistler T, Regnery HL, Kendal AP. Antigenic and genetic characterization of the haemagglutinins of recent cocirculating strains of influenza B virus. J Gen Virol 1992;73:2737-42.

12) Air GM, Gibbs AJ, Laver WG, Webster RG. Evolutionary changes in influenza B are not primarily governed by antibody selection. Proc Natl Acad Sci USA 1990;87:3884-8.

13) Luo C, Morishita T, Satou K, Tateno Y, Nakajima K, Nobusawa E. Evolutionary pattern of influenza B viruses based on the HA and NS genes during 1940 to 1999: origin of the NS genes after 1997. Arch Virol 1999;144:1881-91.

14) McCullers JA, Wang GC, He S, Webster RG. Reassortment and insertion-deletion are strategies for the evolution of influenza B viruses in nature. J Virol 1999;73:7343-8.

15) Nerome R, Hiromoto $Y$, Sugita $S$, Tanabe N, Ishida $M$, Matsumoto M, Lindstrom SE, Takahashi T, Nerome K. Evolutionary characteristics of influenza $\mathrm{B}$ virus since its first isolation in 1940: dynamic circulation of deletion and insertion mechanism. Arch Virol 1998;143:1569-83.

16) Barr IG, Komadina N, Hurt A, Shaw R, Durrant C, Iannello P, Tomasov C, Sjogren H, Hampson AW. Reassortants in recent human influenza A and B isolates from South East Asia and Oceania. Virus Res 2003;98:35-44.

17) Chen GW, Shih SR, Hsiao MR, Chang SC, Lin SH, Sun CF, Tsao KC. Multiple genotypes of influenza B viruses cocirculated in Taiwan in 2004 and 2005. J Clin Microbiol
2007;45:1515-22.

18) Nah SY, Park SE, Park JY, Lee HJ. Epidemiology of influenza virus over 8 years $(1990 \sim 1998)$ in Seoul, Korea. Korean J Infect Dis 1999;31:210-6.

19) KCDC. Influenza Sentinel Surveillance Report, 2007 2008. Number 292008.

20) Yamashita M, Krystal M, Fitch WM, Palese P. Influenza B virus evolution: co-circulating lineages and comparison of evolutionary pattern with those of influenza $\mathrm{A}$ and $\mathrm{C}$ viruses. Virology 1988;163:112-22.

21) Pechirra $P$, Nunes B, Coelho A, Ribeiro C, Gonçalves P, Pedro S, Castro LC, Rebelo-de-Andrade H. Molecular characterization of the HA gene of influenza type B viruses. J Med Virol 2005;77:541-9.

22) Lindstrom SE, Hiromoto $Y$, Nishimura $H$, Saito T, Nerome R, Nerome K. Comparative analysis of evolutionary mechanisms of the hemagglutinin and three internal protein genes of influenza B virus: multiple cocirculating lineages and frequent reassortment of the NP, M, and NS genes. J Virol 1999;73: 4413-26.

23) Hwang YO, Seo BT, Choi BY. Analysis of isolation and subtyping of influenza virus in Seoul, during 1999 2003. J Bacteriol Virol 2004;34:67-74

24) Hoffmann E, Mahmood K, Yang CF, Webster RG, Greenberg $\mathrm{HB}$, Kemble G. Rescue of influenza B virus from eight plasmids. Proc Natl Acad Sci USA 2002;99:11411-6.

25) Stockton J, Ellis JS, Saville M, Clewley JP, Zambon MC. Multiplex PCR for typing and subtyping influenza and respiratory syncytial viruses. J Clin Microbiol 1998;36:2990-5. 